\title{
'Occasional Music: A Symposium on the Work of Jonathan Lethem'
}

\author{
Birkbeck College, University of London, 10 July 2010
}

\begin{abstract}
Zara Dinnen
JONATHAN LETHEM'S WORK IS CRITICALLY ENGAGED with themes of genre, space, place, urban culture, social history, pop culture, music, cinema, digital culture, and his native New York. Traversing all these themes (and this list is by no means exhaustive), Lethem's writing is ripe for scholars working on contemporary American fiction, but also from disciplines as diverse as geography, comic book studies and law. Prior to this symposium there had not existed a forum for scholars working on Lethem to come together; published academic work had been disparate. Occasional Music was a one-day event bringing together scholars from the UK and USA, all of whom engage with Lethem's work in a diverse array of contexts. The event was organised by Dr Joe Brooker with the aim of providing an opportunity for academics to hear and discuss each other's research. However, there was also the added pleasure (or pressure, perhaps, for those speaking), of Lethem's attendance. He took part in a Q\&A session at the end of the day, and read from a new non-fiction work as well as from his current novel-in-progress.

As Brooker explained in his opening remarks, the title of the event is taken from Lethem's first published novel, Gun with Occasional Music, and nods to both this early work and to the occasional music that is itself a theme of Lethem's work (something he touches upon in the audio interview, available as this issue's Dandelion podcast). It gestures towards the idea that the novel 'moves in and out of the functional and the lyrical, between inconspicuous prose and a kind of music of language-a stylistic grace, notes, flights and elaborations-we can find in Lethem's writings'. The image of 'flights and elaborations' resonated throughout the day's proceedings, from which emerged tacit connections that subtly appear, vanish and reappear throughout Lethem's writing and the critical work that surrounds it.

The day began with the panel 'The American Century'. Papers by Samuel Cohen and Richard Greenwald (the latter ably read by Bianca Leggett
\end{abstract}


in Richard's absence) engaged with Lethem's 2003 novel The Fortress of Solitude (hereafter TFoS). Cohen situated this novel in a recent history of American literature framed by a peculiarly American decade-one that began with the fall of the Berlin Wall and the end of the Cold War, and that ended on 11 September, 2001. Reading TFoS as a novel about endings, nostalgia, and mourning, this first paper began a consideration of the ideals of 'communities', and of representations of autonomous temporalities in Lethem's writing (themes that would recur throughout the day). Using Derrida's formulation of the 'future anterior', Cohen considered the curious functions of contingency and 'history' that play out in $\mathrm{TFOS}$ :

\begin{abstract}
Fortress isn't just aware of contingency, it is aware of the hidden centrality of the future and its unknowability to the way we see the past. We construct our narratives of the past to lead not to where we are-which can't really be known either-but to the particular future which we hope will arrive someday.
\end{abstract}

Greenwald's paper, 'Find Myself a City to Live In', took as its starting point the way that within Lethem's novels the characters tell us about 'community' through their removal or dislocation from their own communities. With particular focus on the New York novels, Greenwald linked Lethem's writing to the general notion that 'the relationship many New Yorkers have to their city depends on the stories they tell about their neighbourhood'. This paper, like Cohen's, was a reflection on continually morphing ideas and ideals of 'community', drawing out these themes by considering representations of gentrification and urban identity throughout TFoS, and critically linking them to a wider social historical, and geographical field of study.

The second panel of the day, 'The Outlaw of Genre', featured papers by James Peacock and Benjamin Widiss (also in absentia, this paper read by Dennis Duncan) on some of Lethem's more distinctly 'genre-bending' work: Girl in Landscape and Motherless Brooklyn. The title of the panel gives a good indication of the approaches taken by Peacock and Widiss. In each instance genre was understood to be both present and absent in Lethem's work-a complex reading trope. Lethem's own reluctance to call himself a writer of any specific genre casts him as an outlaw to many of the communities that appreciate his novels. Lethem's stance conversely highlights how central the theme of genre is to his work, but it is still not the defining logic of his writing (as it is in genre fiction). And so genre is the outlaw in the imaginary worlds of Lethem's fiction; it skulks around, a 'hidden absence'. Peacock's paper considered representations of excess, reading and interpretation as ethical experiences in Girl in Landscape. It too looked to the presence of mourning, and the overlap of endings and beginnings; to themes of temporal instability. Widiss's paper picked up very neatly from Peacock's (particularly given that he wasn't actually in attendance), outlining how the protagonist in Girl in Landscape, the thirteenyear-old, motherless Pella, is in fact a repetition, a beat that runs through several of Lethem's novels. The figure of an orphaned thirteen-year-old, one who is charged with assembling or disassembling a version of the family unit, is central to Amnesia Moon and Motherless Brooklyn - published either side of Girl 
in Landscape. Widiss's paper linked this persistent character to a 'turn' taken by Lethem in his writing (his return to Brooklyn, his turn away from Science Fiction), and read this moment represented in the fiction as turns that these young characters must take toward or away from themselves, their communities, and their nominal families. In Widiss's paper the ontological instability that underwrites Motherless Brooklyn, stemming from the protagonist's Tourette's Syndrome, offers Lethem a framework in which to explore geographical, personal and cultural landscapes outside of a generic field. Despite disparate critical contexts, continuities emerged from these papers: themes of fleeting communities; moments of fleeting stability; a fluid relationship to genre.

Developing these themes, but again through a very different critical window, the third panel of the day focused on cultural interventions in Lethem's work-pop culture, pulp modernism, intertextuality, and literary plagiarism in the digital realm. Titled 'The Frivolous Now' this panel featured papers from Tony Venezia and myself on Lethem's relationship with comic books throughout his work, and his engagement with issues of plagiarism in the essay 'Ecstasy of Influence' and 'The Promiscuous Materials Project'. Venezia's paper took as its starting point the role of comics in the childhood relationship of Dylan and Mingus in TFoS: 'Comics as material objects and storytelling devices offer a momentary point of contact for Dylan and Mingus.' Venezia's thinking about the momentary nature of the connection between the two boys, mediated through the shared imaginary world of the Marvel comics they covet, once again riffed on representations of temporary communities and fleeting ideals. Venezia's use of this moment from TFoS to consider Lethem's involvement with comics and superheroes, and other author/fan interventions, enabled a reading of Lethem's work and interests that placed them in a broad 'web of subcultural connections', a point Lethem develops in the audio interview. My own paper looked at Lethem's 2007 essay 'Ecstasy of Influence’ as a way of considering how his writing, in this essay but also throughout his work, may represent a critical juncture for literature produced in this digital age. I argued that in the essay Lethem uses an aesthetic programme of remediation to carve out a perpetually elusive middle space between a new media practice of reapproriation, and a literary notion of influence.

The final panel featured Adam Gearey from the Birkbeck Law department. Gearey's paper, 'Lethem's Science of Love', was a reading of the novel As She Climbed Across the Table (1997) as, 'the most modern of handbooks on the affairs of the heart', 'an amorous science, an interpretation of ambiguous figures and experiments', and 'written to deliberately play with the academic reader'. This paper tasked itself with decoding the various tropes of reading and interpretation at work in As She Climbed Across the Table through two frameworks: the politics and ethics of science, with reference to Nietzsche's The Gay Science, and the politics and ethics of love, with reference to works on courtly love and the figure of 'the lover' as represented in Roland Barthes's A Lover's Discourse. The paper also touched upon some of the many intertextual references at work in the novel, particularly cinema-Vertigo, His Girl Friday and the generic romantic comedy. Like all the papers of the day, Gearey's reading was elucidating and fresh, introducing a unique and original approach 
to Lethem's work. And yet, this paper again posited familiar recognitions-in particular the way Lethem's writing is itself a homage to the texts that have influenced him, and to the very act of reading - as had been suggested by Peacock and Venezia, and by so much of the discussion in between panels (which, like those gaps in a comic strip, remain largely undocumented here). 'Lethem's Science of Love' also zoomed in again on representations of the middle, of temporary and transitory communities, although in Gearey's arguments these moments had arisen from collision and deferral, rather than allusion and elision:

[It is] the collision of two different discourses within this book; the discourse of love and the discourse of science [...] that perhaps allows us to see that the master code is that of force, the attraction and repulsion of all bodies.

After the final panel Lethem read from his recently published critical work, They Live, and from his novel-in-progress, provisionally titled Dissident Gardens. The enjoyment of the room at hearing these pieces read was palpable. Listening to Lethem's own thoughts on the progression of his new work seemed to confirm the relevance of the day's discussions, and to justify the direction of the interest shown in his work, demonstrating the ongoing broadening and deepening of his pre-existing interests within his new writing.

The Question and Answer session that followed gave an opportunity for Lethem to speak back to the various papers and discussions of the day. By way of a conclusion to this report, and an introduction to the recorded interview, I would like to offer some quotes from the Q\&A. I have chosen these particular excerpts as a way of cementing some of the themes discussed above, but this time through the author's own words.

On genre: 'My dying breath will be "OK, I was a Science Fiction writer, I know, I know!”'

On 'influence', intertextuality, and an infinite map of cultural referents: 'My sense [is] that you're born into a world of reference-in-progress. [...] For me, for instance, as deep as my relationship to an actor like Humphrey Bogart and Edward G. Robinson, [...] the first way I knew those voices and those styles and those stances was Bugs Bunny pretending to be those guys. I knew something was going on there, I didn't know what it was but I felt it. [...] For anyone my age group you understand who Elvis Presley is first by jokes about Elvis Presley; you have to build your way back to the source. This is universal, and not a mistake but actually a part of cultural experience that is to me, very enthralling.'

On 'hidden absence' and the value of the 'opaque reference': 'I like the way stories feel when they're allegorical but you don't know [what the allegory is], [...] like Narnia was interesting until you found out about Christ. [...] You sense the power of reference and allegory and connection but it's also hidden, it's there and not there.' 
On the long passages, and his accidentally-on-purpose losing the plot in Chronic City: 'I was thinking about the long scene in general and it comes partly from watching John Cassavetes's films and thinking about what makes them so different from Hollywood films. [...] I just felt that life happens in long scenes and I wanted to increase my commitment to pushing scenes to where one thing happened and then another; instead of there being a sort of take away, [...] like comic book panels or like the short chapters in As She Climbed Across the Table. I wanted to abide with characters through a day or a night.'

On the commons; on temporary communities of a particular place and time, or in culture; on graffiti and fanzines: 'A version of the middle space is the ground you only temporarily occupy where things are possible because of your understanding of the temporal nature of your occupation. [...] The freedom of the commons is also to do [with] the opaque gesture, the self-defeating gesture to make something impossible-an assertion that has destruction built into it, or opposition built into it.'

On early music journalism (Paul Williams, Pauline Kael, and, later, Greil Marcus, Lester Bangs), and the poignancy of their writing versus the poignancy of their lives: 'They faced absolute scorn, against [the idea] you would put pen to paper to describe these ephemeral objects; [...] they invented a realm of study in the context of contempt'. 'Their field of reference was that of my parents. [...] I wasn't a rebel, my parent's generation were cooler than the kids I knew. The lives and the writing are bound up for me.'

And finally, on Bob Dylan (who, without doubt, haunted the day as much as he does Lethem's writing): 'A slight name-dropping anecdote [...] on the notion of this history of instruction in the art of love: When I interviewed Dylan one of my side questions that I knew was useless for the article but that I wanted to know was, there's a line in Modern Times, "I've been sitting here studying the art of love," and I knew it was a book reference, I should've known it was Ovid, but I said was it Kenneth Koch? [...] He played dumb which he likes to do about references, a lot [...] but I took that as an opportunity to make the first edition of the Kenneth Koch a thank-you gift. But anyway, Dylan is the backdrop of everything for me, [there are] so many lyrical echoes.'

A few acknowledgements: Thanks to Jonathan Lethem for being so generous with his time, to Joe Brooker for organising a great event, and to Susan Civale and Matt Parker for their help with the podcast.

\section{Jonathan Lethem}

JONATHAN LETHEM is an American author who has been publishing works of fiction and non-fiction since the early 1990s. Born in Brooklyn in 1964, he moved to Berkeley in 1984. His early published works are often regarded as genre-bending and openly owe a happy debt to science fiction, fantasy, the 
Western, and crime noir. These early works were written in California, a place which implicitly and explicitly influenced many of Lethem's books and stories throughout the time he was there. In 1998, he published Girl in Landscape, arguably a transition novel which begins a return to his native city of New York. With the publication of Motherless Brooklyn (1999), Lethem came to mainstream attention, winning a National Books Critics Circle Award. Around this time he also moved back to his native city, and in the 2003 novel The Fortress of Solitude he fully explores his own history in and around the streets of Brooklyn. In 2005, he received a MacArthur fellowship, and in 2010 an honorary doctorate from the Pratt Institute, New York. Alongside his novels, Lethem has written many short stories, published in journals, magazines and on his website; essays, most famously 'Ecstasy of Influence: A Plagiarism Mosaic', published in Harper's in 2007; he is co-author of the revived Marvel comic book Omega the Unknown; he has interviewed Bob Dylan for Rolling Stone; he has edited a collection of music journalism, and a collection of writing on the topic of 'amnesia', and was editor of the Library of America anthology of the work of Philip K. Dick.

Birkbeck College, University of London 